\title{
Age of Great Grey Owls Stirix nebulosa observed in Scandinavia in 2012 as revealed by digital photos in the national species report archives
}

\author{
Alderssammansättning hos lappugglor Strix nebulosa observerade i Skandinavien \\ 2012 bestämd med hjälp av digitala fotografier inskickade till Artdatabankens artportal
}

\author{
ROAR SOLHEIM
}

\begin{abstract}
Record breaking numbers of breeding Great Grey Owls Strix nebulosa were reported in Sweden and Norway in 2010 and 2011, followed by 4105 observations in 2012 as revealed by the national Species archives. Based on locality id numbers, at least 144 individuals were reported with photos which could be used to age the individuals. The majority $(76 \%)$ of these birds were young birds hatched in 2011 (83\% including birds aged probably $2 \mathrm{CY}$ ). Among dead owls brought to the Natural History Museum in Stockholm, the percentages of owls hatched in 2011 were similar (78\% and 88\%). The high percentage of young owls could be caused by young birds hunt-

ing closer to human settlement than older birds, but more likely it was caused by a higher total production of young in south-central Scandinavia in 2011 than in 2010. This study shows that photos in the national species archives reveal the age structure of the Great Grey Owl population, fundamental data to understand the current distributional expansion of this species. This method may also be applied to other species.

Roar Solheim, Agder Natural History Museum, P.O. Box 1887 Gimlemoen, N-4686 Kristiansand.

E-mail: r-solhe3@online.no
\end{abstract}

\section{Abstract}

Received 14 January 2014, Accepted 11 March 2014, Editor: S. Svensson

\section{Introduction}

The Great Grey Owl Strix nebulosa has expanded its range in NW Europe the last decades (Lawicki et al. 2013). In Sweden, there was a marked increase in population size from 1960 to the late 1980s (Stefansson 1997). According to Stefansson (1997), the autumn population in Sweden was probably at least 3000 individuals in 1987, which was a very good breeding year. Since 1989 the Great Grey Owl has become a regular breeder in SE Norway (Solheim 2009a), and in 2011 a total of 22 nests or breeding attempts were recorded in the county of Hedmark (Berg et al. 2011). Also in Sweden 2011 was a record-breaking breeding year for Great Grey Owls, with an estimated late summer population of 4000-4500 individuals (Stefansson 2013). Several individuals found dead or photographed in SW Norway and Sweden in the autumn of 2009 were adult birds as judged by their moult patterns (Solheim 2009). This sparked a study of the moult sequences and patterns of Great Grey Owls, based on skinned birds ringed as nestlings (Solheim 2011). As juvenile and adult flight feathers are usually markedly different and easily recognizable, it is possible to age a Great Grey Owl at least up to the spring after its second flight feather moult. The moult patterns can also be detected on live birds in the field, and documented on digital photographs (Solheim 2009a, 2010, 2011, 2013).

\section{Methods}

The Swedish and Norwegian species report archives collect data on animals and plants (Artdatabanken.se and Artsdatabanken.no). Both countries use the same digital database based on the Swedish Species Project started in 2002, where informers can make daily entries of their observations. The bird pages are extensively used by ornithologists, both amateurs and professionals, and represent an easily accessible up-to-date register of a species' observed distribution and recent presence in the two Scandinavian countries. When reporters document their observations with digital photos, extra information can be gained. The number of reports of Great Grey Owl observations peaked in 2012, with more than 4000 single reports filed.

I first downloaded all Swedish entries of Great Grey Owl observations up to 16 November 2012, and the remaining reports on 7 January 2013, and 
manually counted the number of entries by month. On 21 August 2013 I downloaded all reports on Great Grey Owl observations from Norway and on 22 August from Sweden. In the last check of the data from Sweden I sorted observations by landscape before downloading the reports. While the freely accessible number of reports from Norway for the whole 2012 was only 58 , there were a total of 3998 reports from Sweden. After I gained access to the total material from Norway and Sweden, including reports with restrictions on publication, the total number of reports from Norway amounted to 107, compared to 4263 from Sweden (265 restricted reports). The Norwegian reports thus made up a mere $2.4 \%$ of all Great Grey Owl reports from Scandinavia in 2012 (Table 1). All entries with photos of the owl(s) reported were inspected on a high quality PC screen, and all images which

Table 1. Reports of Great Grey Owl observations from Sweden and Norway in 2012. For Sweden only openly accessible reports are included, which could be separated to landscape. Number of localities based on number of separable dots on the species maps as shown on the Species Archives websites. +images: images which can be used for age determination of bird. Minimum number of individuals as shown on +images. Parentheses: restricted localities included.

Rapporter om observerade lappugglor i Norge och Sverige 2012. Från Sverige är skyddade observationer ej medtagna. Antal lokaliteter är antal prickar som framkommer $i$ varje landskapskarta från Artdatabankens register. +images: foton som kan användas för att åldersbestämma fågeln. Minimum antal fåglar på +foton. Parentes: antal med skyddade lokaler inräknade.

\begin{tabular}{|c|c|c|c|c|c|c|}
\hline $\begin{array}{l}\text { Landscape/ } \\
\text { land }\end{array}$ & & $\begin{array}{l}\text { Min. } \\
\text { no. of } \\
\text { localities }\end{array}$ & $\begin{array}{c}\text { Number } \\
\text { of } \\
\text { reports }\end{array}$ & $\begin{array}{l}\text { Reports } \\
\text { with } \\
\text { images }\end{array}$ & $\begin{array}{l}\text { Reports } \\
\text { with } \\
+ \text { images }\end{array}$ & $\begin{array}{c}\text { Min. } \\
\text { no. of } \\
\text { individuals }\end{array}$ \\
\hline \multicolumn{7}{|l|}{ Lappland } \\
\hline & $\mathrm{T}$ & 1 & 1 & 0 & 0 & 0 \\
\hline & $\mathrm{Lu}$ & 3 & 4 & 0 & 0 & 0 \\
\hline & $\mathrm{Pi}$ & 10 & 11 & 0 & 0 & 0 \\
\hline & Ly & 7 & 7 & 0 & 0 & 0 \\
\hline & Às & 1 & 1 & 0 & 0 & 0 \\
\hline Jmtl & & 8 & 12 & 3 & 2 & 2 \\
\hline $\mathrm{Hjd}$ & & 1 & 1 & 0 & 0 & 0 \\
\hline $\mathrm{Nb}$ & & 24 & 38 & 4 & 0 & 0 \\
\hline $\mathrm{Vb}$ & & $52(53)$ & 100 & 7 & 3 & 3 \\
\hline Ång & & 58 & 230 & 51 & 20 & 13 \\
\hline Mpd & & 72 & 299 & 90 & 55 & 23 \\
\hline Hsl & & $79(81)$ & 189 & 9 & 2 & 2 \\
\hline Dlr & & $37(43)$ & 118 & 27 & 15 & 5 \\
\hline Gstr & & 32 & 186 & 33 & 15 & 5 \\
\hline Upl & & $77(81)$ & 1059 & 170 & 40 & 12 \\
\hline Srm & & 70 & 780 & 166 & 73 & 31 \\
\hline Vstm & & $26(38)$ & 54 & 14 & 5 & 3 \\
\hline Nrk & & 15 & 106 & 9 & 5 & 3 \\
\hline Vrm & & $37(39)$ & 163 & 40 & 20 & 8 \\
\hline Ög & & 15 & 132 & 16 & 6 & 3 \\
\hline $\mathrm{Vg}$ & & 39 & 181 & 32 & 10 & 5 \\
\hline Dls & & 7 & 8 & 2 & 2 & 2 \\
\hline Boh & & 6 & 30 & 11 & 8 & 1 \\
\hline SM & & $18(21)$ & 130 & 42 & 18 & 7 \\
\hline HL & & 3 & 5 & 1 & 0 & 0 \\
\hline $\mathrm{Bl}$ & & 6 & 47 & 11 & 2 & 1 \\
\hline Sk & & 6 & 106 & 29 & 9 & 2 \\
\hline \multicolumn{7}{|l|}{ Sums } \\
\hline Sweden & & $710(740)$ & 3998 & 767 & 310 & 131 \\
\hline Norway & & 33 & 107 & 46 & 13 & 13 \\
\hline Total & & $743(773)$ & 4105 & 813 & 323 & 144 \\
\hline
\end{tabular}




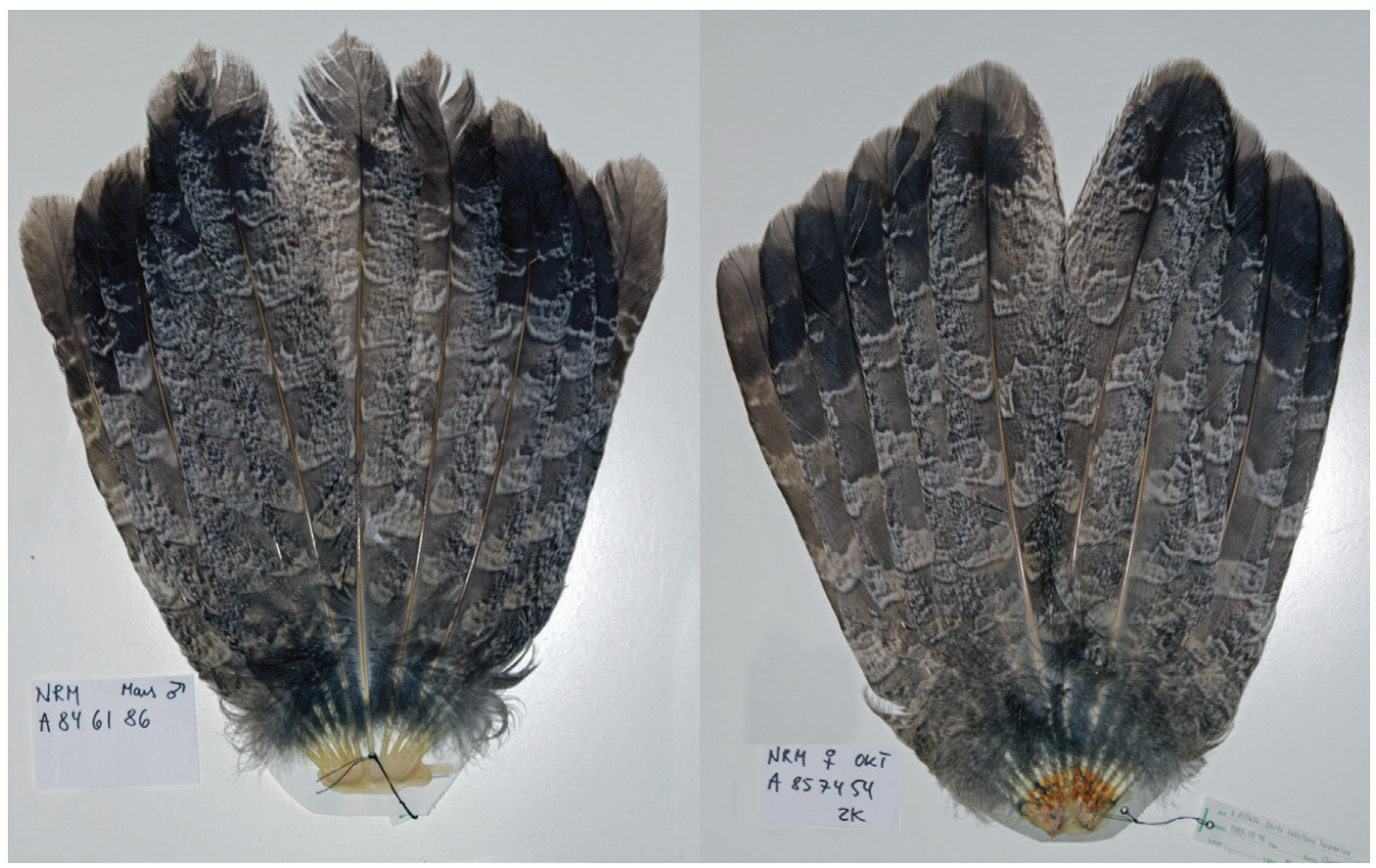

Figure 1. Tail of young Great Grey Owl in age category 1CY-2CYs (left), showing typical juvenile feathers, compared to a tail of a bird that has moulted once (2CYa; right). The juvenile feathers are sharply pointed with a diffuse, dark crossbar close to the whitish edge. The adult tailfeathers are broader with rounded tips, and no diffuse crossbars between the outer distinctive dark crossbar and the tip of the tailfeathers. See also Figure 2 and 3. Specimens photographed in the Natural History Museum, Stockholm.

Stjärt av ung lappuggla (vänster) med juvenila fjädrar, sammanliknat med stjärt från en uggla som har ruggat första gången. Juvenila fjädrar är spetsiga med en ljus yttre kant. Adulta stjärtpennor är bredare, avrundade och utan diffusa mörka band utanför det markanta yttre tvärbandet. Se även Figur 2 och 3.

might reveal the age of the owl were downloaded for closer inspection.

Birds are aged according to the calendar year approach. A juvenile is thus $1 \mathrm{CY}$ until 31 December, when it becomes a $2 \mathrm{CY}$ bird. Because wing feather moult takes place during summer, I specified if an owl was from spring (s) or autumn (a). A $2 \mathrm{CYs}$ owl has not moulted any wing or tail feathers yet, while a 2 CYa owl has an adult tail and some typical adult feathers in the wing. For further explanation; see Solheim (2010).

The age of most of the owls was judged by the character of their tail feathers (Figure 1). On the images where an outspread wing was in focus and visible, the moult sequence was used to age the owl after the $2 Y$ stage. It turned out to be next to impossible to sort out localities of photos accompanying the selection of restricted reports from Sweden, so these photos were excluded in the Swedish material in Table 3.

When searching for reports in the species ar- chives, one can choose different ways of selections and presentations. Species observations can be searched for specific periods, regions, and combinations. When presenting the reports, one can choose distribution maps, lists, histograms and others. The different ways of searching and presenting result in different numbers of reports displayed. I do not know the reason for these discrepancies, and have also been unable to find an explanation for them. However, as the listed observations are the main source for this work, I have used the numbers from these listings as the number of reports from each country and landscape (Sweden).

The downloading of Great Grey Owl reports from Sweden in January and August 2013 gave different numbers of entries. The report strings from January were manually counted for each day and month (Table 2), resulting in 3103 reports, of which 547 were supported by photos. The count from August, sorted by landscapes, gave a total of 3998 entries (Table 1), while a count of all pin- 
Table 2. Great Grey Owl reports by month from Sweden 2012, as revealed by downloads from the national Species Archive on 16 November 2012 and 7 January 2013. Based on openly accessible reports only. * days with reports/days in month.

Antal rapporter om lappuggleobservationer i Sverige 2012 när rapporterna laddades ner från Artportalen den 16 november 2012 och 7 januari 2013. Inga skyddade lokaler inräknade. *: dagar med observationer/ dagar per månad.

\begin{tabular}{lcccc}
\hline Month & $\begin{array}{c}\text { Days } \\
\text { with } \\
\text { reports* }\end{array}$ & $\begin{array}{c}\text { Number } \\
\text { of } \\
\text { reports }\end{array}$ & $\begin{array}{c}\text { Reports } \\
\text { with } \\
\text { images }\end{array}$ & $\begin{array}{c}\text { Mean to } \\
\text { reports per } \\
\text { report day }\end{array}$ \\
\hline January & $26 / 31$ & 191 & 46 & 7.3 \\
February & $29 / 29$ & 188 & 53 & 6.5 \\
March & $31 / 31$ & 810 & 142 & 26.1 \\
April & $30 / 30$ & 616 & 92 & 20.5 \\
May & $31 / 31$ & 504 & 67 & 16.3 \\
June & $30 / 30$ & 207 & 50 & 6.9 \\
July & $28 / 31$ & 101 & 17 & 3.6 \\
August & $27 / 31$ & 69 & 7 & 2.6 \\
September & $28 / 30$ & 114 & 26 & 4.1 \\
Oktober & $29 / 31$ & 110 & 15 & 3.8 \\
November & $27 / 30$ & 134 & 21 & 5.0 \\
December & $24 / 31$ & 59 & 9 & 2.5 \\
\hline Sum & & 3103 & 547 & 9.1 \\
\hline
\end{tabular}

pointed localities from Sweden when sorting observations onto maps, gave a total of 4465 reports. The numbers of report strings from August 2013 have been used, as I at this time gained access to the total material from both countries.

\section{Results}

Of a total sample of 4105 report strings of observed great grey owls, $813(19.8 \%)$ reports included one or more photographs of the observed owl(s). In 323 $(39.7 \%)$ of these reports at least one of the images (termed +images) could be used for aging the owl. Based on the locality names these photos were judged to portray a minimum of 144 individuals (Table 1).

Of 144 birds, 102 observed in spring had juvenile tail feathers (Figure 2) and these were all 2CY birds from 2011. Another 9 birds were classified as probably belonging to the same age category (Table 3). Only 3 individuals could be aged as $3 \mathrm{CY}$ birds, hatched in 2010, while 16 birds were $3 \mathrm{CY}$ or older (Figure 3). Two individuals were classified as probably at least 3CY birds. From autumn 2012 there were 10 individuals which were classified as $2 \mathrm{CY}+$, based on their adult tail feathers. Only two

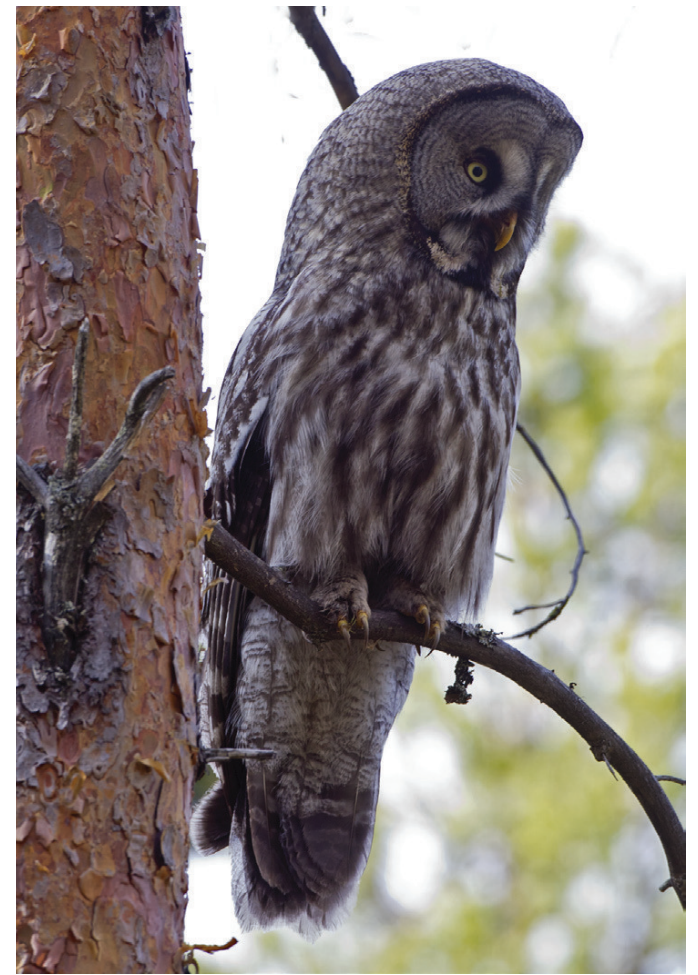

Fiure 2. Young, female Great Grey Owl with typical juvenile tail feathers (2CYs). This female was banded as a chick on an artificial breeding platform close to lake Siljan in central Sweden in 2010 and controlled as a breeding bird in Hedmark county, eastern Norway, in 2011.

Ung lappugglehona med karaktäristiska juvenila stjärtpennor ( $2 K$ vår). Denna hona blev ringmärkt som unge på en boplattform vid Siljan 2010 och kontrollerades som häckfågel i Hedmark, östra Norge 2011.

of the birds observed in autumn had typically juvenile tail feathers, revealing that they must have been hatched in 2012 .

The Swedish species report archives secretariat provided a list of 38 photos accompanying 19 of the restricted reports. While 18 of the photos could not be used for aging, rendering 7 individuals as un-aged, 12 individuals could be aged based on the other 20 images. Of these 9 individuals were $2 \mathrm{CY}$ birds, 1 was probably a $2 \mathrm{CY}$ bird, while 2 individuals were classified as $3 \mathrm{CY}+$ and $5 \mathrm{CY}+$ birds respectively.

When the report strings from Sweden, downloaded in November 2012 and January 2013 were sorted to monthly reports (tab. 2), March had highest number of reports (810), followed by April (616) and May (504). Uppland and Södermanland topped the list as the landscapes with highest num- 
Table 3. Age distribution of Great Grey Owls in Sweden (to landscapes) and Norway in 2012, identified from photos. Photos from restricted reports from Sweden not included.

Alderfördelning av observerade lappugglor I Sverige (efter landskap) och Norge 2012, identifierade frän foton. Foton från skyddade lokaler I Sverige inte medtagna.

\begin{tabular}{lrrrrrrr}
\hline Landscape & $1 \mathrm{CY}$ & $2 \mathrm{CY}$ & $\begin{array}{r}\text { Prob } \\
\text { C }\end{array}$ & $2 \mathrm{CY}+\mathrm{a}$ & $3 \mathrm{CY}$ & $3 \mathrm{CY}+\mathrm{s}$ & $\begin{array}{r}\text { Prob } \\
\text { C }+\mathrm{s}\end{array}$ \\
\hline Jmtl & 0 & 1 & 0 & 1 & 0 & 0 & 0 \\
Vb & 0 & 1 & 0 & 0 & 0 & 2 & 0 \\
Ang & 0 & 12 & 0 & 0 & 0 & 1 & 0 \\
Mpd & 0 & 19 & 0 & 1 & 1 & 2 & 0 \\
Hsl & 0 & 2 & 0 & 0 & 0 & 0 & 0 \\
Dlr & 0 & 3 & 1 & 0 & 0 & 1 & 0 \\
Gstr & 0 & 5 & 0 & 0 & 0 & 0 & 0 \\
Upl & 0 & 8 & 0 & 3 & 0 & 1 & 0 \\
Srm & 1 & 23 & 1 & 0 & 1 & 4 & 1 \\
Vstm & 0 & 2 & 1 & 0 & 0 & 0 & 0 \\
Nrk & 0 & 3 & 0 & 0 & 0 & 0 & 0 \\
Vrm & 0 & 5 & 0 & 1 & 0 & 2 & 0 \\
Ög & 0 & 1 & 1 & 0 & 0 & 0 & 1 \\
Vg & 0 & 3 & 1 & 1 & 0 & 0 & 0 \\
Dls & 0 & 1 & 1 & 0 & 0 & 0 & 0 \\
Boh & 0 & 1 & 0 & 0 & 0 & 0 & 0 \\
SM & 1 & 2 & 1 & 1 & 0 & 2 & 0 \\
HL & 0 & 0 & 0 & 0 & 0 & 0 & 0 \\
Bl & 0 & 0 & 1 & 0 & 0 & 0 & 0 \\
Sk & 0 & 1 & 0 & 1 & 0 & 0 & 0 \\
\hline Sum & 2 & 93 & 8 & 9 & 2 & 15 & 2 \\
Norway & 0 & 9 & 1 & 1 & 1 & 1 & 0 \\
Sum all & 2 & 102 & 9 & 10 & 3 & 16 & 2 \\
\hline & & & & & & & 144 \\
\hline
\end{tabular}

ber of reports (1059 and 780 respectively; Table 1). A majority of the Great Grey Owls reported from Norway were sighted in the coastal areas from Vest-Agder county to Østfold county, and also in Sweden more observations were reported close to coastal areas (Figure 4).

\section{Discussion}

Because the 2CY+ birds from autumn 2012 are non-conclusive as to whether they were hatched in 2011 or earlier, they were excluded from the age distribution comparisons. This means that at least 102 of $134(76.1 \%)$ Great Grey Owls on +images from 2012 were hatched in 2011. When including the individuals classified as probably $2 \mathrm{Y}$ birds, there were as many as 111 of 134 birds $(82.8 \%)$ from 2012 that were hatched in 2011. Stefanssons table 3 (2013) lists 69 Great Grey Owls found dead in 2012 and registered by the Swedish Natural History Museum. In his table 3, 41 of these birds are aged, with 32 as $2 \mathrm{CY}$ birds, and 4 as probably $2 \mathrm{CY}$ birds. The birds from 2011 thus make up $78.0 \%$ of the aged dead birds, and $87.8 \%$ when including the four individuals classified as probably $2 \mathrm{CY}$. Thus, the age distribution in my sample of live birds was very similar to that in the sample of dead birds reported by Stefansson (2013).

The high number of young $2 \mathrm{CY}$ birds is an obvious result of 2011 being the best breeding year ever for Great Grey Owls in Sweden (Stefansson 2013), and Norway (Berg et al. 2011). Both 2010 and 2011 were however vole peak years on the Scandinavian peninsula, with 2011 as an exceptionally good breeding year for several owl species (Berg et al. 2011, Nyhus \& Solheim 2011, Jacobsen et al. 2012). While 2011 was the exceptional Great Grey Owl year in eastern Norway with 22 nests or breeding attempts, both 2010 and 2011 brought high numbers of breeding records in Sweden (77 and 81 nests or breeding attempts; Stefansson 2013). In spite of 2010 being a good breeding year, only 3 of 134 individuals could be classified as 3CY birds in the 2012 reports. Even if we assume that all of the other 3 CY + birds could be 2010-birds, they would maximally make up only $15.7 \%$ of the observed 


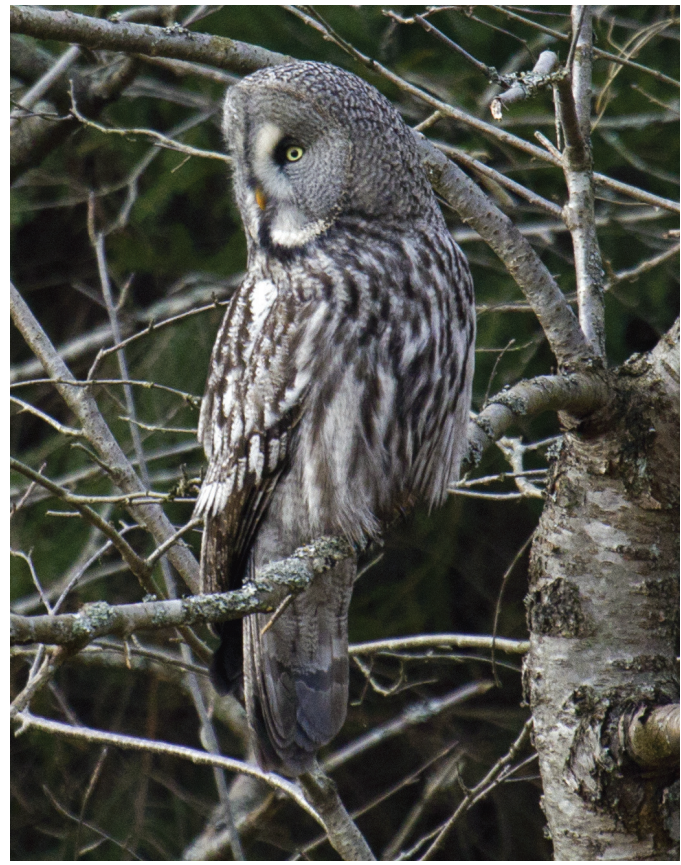

Figure 3. Adult, 3CY+ bird photographed on Tromøya, AustAgder county in southern Norway on 14 January 2012. Note the rounded, broad tail feathers with long distance from the outermost dark band to the tip of the feathers.

Adult $3 K+$ fågel fotograferad på Tromøya, Aust-Agder fylke i Södra Norge 14 januari 2012. Märk de breda, avrundade stjärtpennorna med stort avstånd från det yttre, mörka tvärbandet till fjädrarnas ytterkant.

owls, compared to at least 76.1\% 2011-birds. A hypothetical explanation could be that the 2010 birds had lower survival than the 2011 birds. This does not seem very likely, considering the high abundance of voles through autumn 2010 into the breeding season of 2011, which to the contrary ought to give high survival rates of the young hatched in 2010. Another interpretation could thus be that the number of young great grey owls produced in 2011 outnumbered the 2010 generation at least five times. This could very well be the case in the western part of the Great Grey Owl's distribution range in Scandinavia, as the number of recorded nests or breeding attempts in eastern Norway rose from 3 in 2010 to 22 in 2011 (Berg 2010, Berg et al. 2011). As stated by Stefansson (2013), Great Grey Owls are studied in detail only at a few sites in Sweden, leaving vast forest areas subjected to little or no knowledge of their whereabouts.

It is also possible that young Great Grey Owls behave differently than older birds during food shortage. The congregation of reports from March and April, and close to coastal areas, points to birds hunting voles on snow-free fields close to human settlements. This behavior could indicate that the birds observed had trouble finding enough voles in the forest areas. If older birds are more experienced hunters than young ones, one might expect an overrepresentation of young birds among the observed Great Grey Owls. There is however no reason to assume that older owls are less prone to be killed by traffic than younger birds. The high percentage of $2 \mathrm{CY}$ birds among the dead owls from the Natural History Museum in Stockholm (Stefansson 2013) thus supports the interpretation that the population really held a very high proportion of young birds in 2012, since traffic hits make up the majority of mortality amongst these birds. This is in accordance with results found during a winter famine that killed hundreds of tawny owls in southern Norway (Solheim 2006, 2009b), where the proportions of young and older birds were exactly similar in starved and road-killed specimens. Photos of Great Grey Owls from the southern part of Norway during the winter and spring 2011-2012 points to adult birds being as likely as young ones to be observed; of 8 birds, 4 were $2 \mathrm{CY}$, and 4 were older individuals (Solheim unpublished).

The high number of reports from Uppland and Södermanland in Sweden may be caused by high numbers of owls along the eastern coast of central Sweden. However, it may also be explained by the high density of birders in the Stockholm area, with many observers reporting separately on the same individuals. Through the local rarity committees such observations have been lumped together, which made sorting by locality easier in August 2013 than in January 2013.

In Norway a minimum of 63 young fledged from 17 successful great grey owl nests in 2011 (Berg et al. 2011). During winter 2011-2012 no Great Grey Owls were reported seen in the breeding areas of Hedmark county, and remarkably few birds were observed at all in Norway during 2012. Two breeding females controlled in Hedmark county in 2010 and 2011 were hatched on artificial breeding platforms southwest of lake Siljan in central Sweden in 1999 and 2010 respectively (Berg et al. 2011). Because Great Grey Owls have been controlled more than $200 \mathrm{~km}$ away from their birth place, it is not unlikely that both old and juvenile birds may have migrated eastwards from Hedmark into Sweden in late 2011, contributing to the high proportion of young 2CY birds reported in Sweden in 2012. 
Figure 4. Reports of Great Grey Owls from Norway and Sweden in 2012, as revealed through the mapping command of the national species archives. Maps were presented for each country separately, and had to been stitched together after downloading the images.

Rapporter om observerade lappugglor $i$ Norge och Sverige 2012. Kartor från Artdatabanken i Norge och Sverige. Kartorna kan endast laddas ner från varje land, och är sammankoplade $i$ efterhand.

\section{Acknowledgements}

I thank the species report archives in Norway and Sweden for granting me access to the Great Grey Owl observation reports for this study. Geir Sonerud has kindly commented on the manuscript, and Per Göran Bentz translated the text for the Swedish summary. I would also thank all the dedicated ornithologists and bird photographers who send their reports and images to the digital archives, making studies like this one possible.

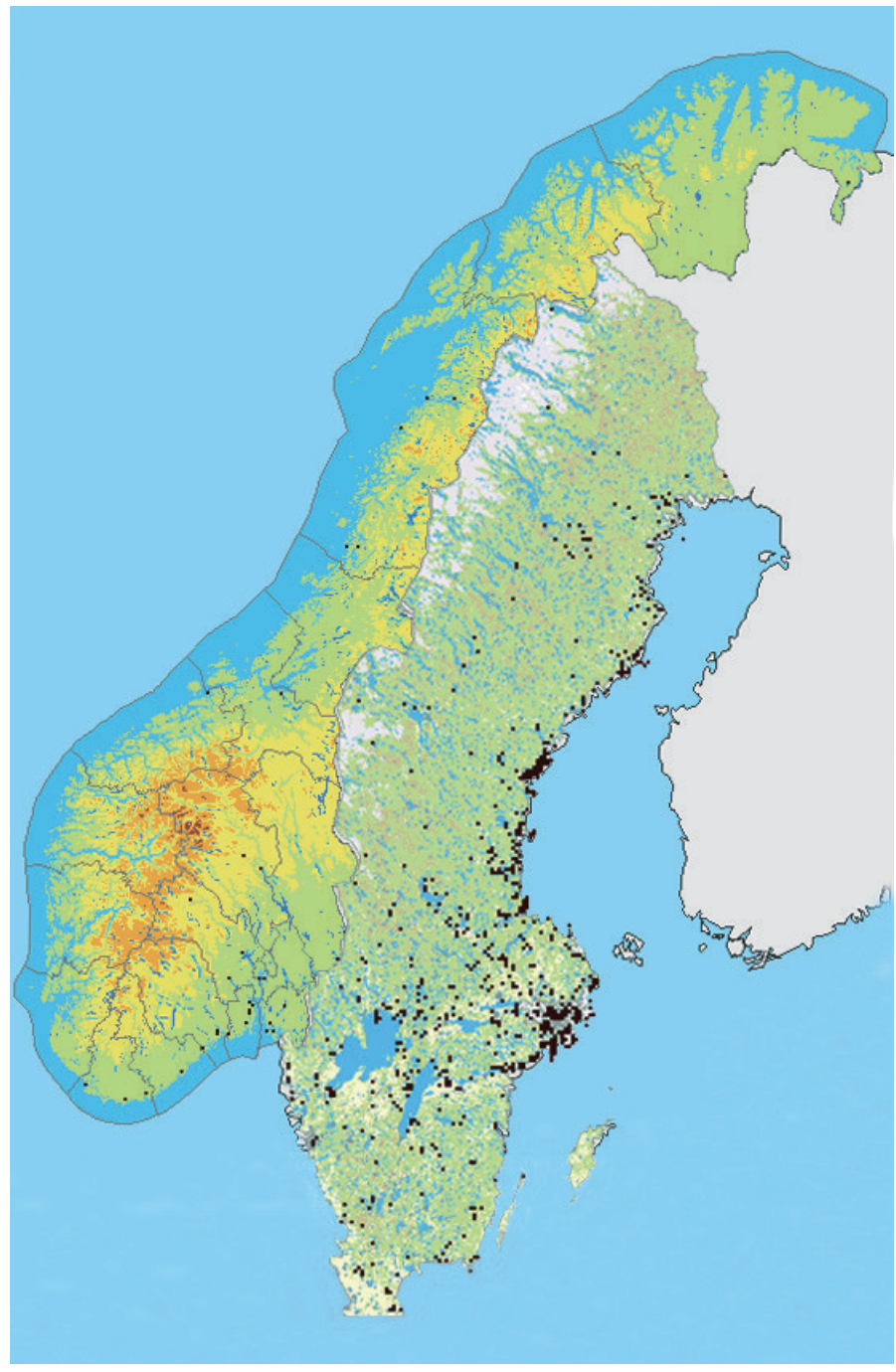

\section{References}

Berg, T. 2010. Lappuglene kommer! Vår Fuglefauna 33: 112-117. (Norwegian).

Berg, T., Solheim, R., Wernberg, T. \& Østby, E. 2011. Lappuglene kom! Vår Fuglefauna 34: 108-115. (Norwegian).

Jacobsen, K-O., Øien, I.J.,Solheim, R. \& Aarvak, T. 2012. Det store snøugleåret 2011. Vår Fuglefauna 35: 12-19. (Norwegian)

Ławicki, Ł., Abramčuk, A.V., Domashevsky, S.V., Paal, U., Solheim, R., Chodkiewicz, T. \& Woźniak, B. 2013. Range extension of Great Grey Owl in Europe. Dutch Birding 35: $145-154$.

Nyhus, G.C. \& Solheim, R. 2011. Grensesprengende slagugler. Vår Fuglefauna 34: 156-163. (Norwegian).

Solheim, R. 2006: Den store kattugledøden vinteren 2006. Agder Naturmuseums Arbok 178: 12-21. (Norwegian). 
Solheim, R. 2009a: Lappugla - en klimaflyktning på vei sydover? Vår Fuglefauna 32: 164-169. (Norwegian).

Solheim, R. 2009b. Age, sex and size of dead Tawny Owls Strix aluco found during winter famine 2006. In: Johnson D.H., Van Nieuwenhuyse, D. \& Duncan, J.R. (eds), Proc. Fourth World Owl Conf. Oct-Nov 2007, Groningen, The Netherlands. Ardea 97(4): 597-601.

Solheim, R. 2010. Kan lappugglor individbestämmas utan infångande och märkning? Vår Fågelvärld 69(2): 8-12. (Swedish).

Solheim, R. 2011. Moult pattern of primaries and secondaries during first and second flight feather molt in Great Grey Owls Strix nebulosa. Ornis Scandinavica 21: 11-19.

Solheim, R. 2013. Digitalfotografering kan skille lappugleindivider. Kornkråka 43: 102-107. (Norwegian).

Stefansson, O. 1997: Nordanskogens vagabond. Lappugglan. Ord \& visor förlag, Skellefteå. (Swedish, English summary).

Stefansson O. 2013. Nordanskogens vagabond. Lappugglan (Strix nebulosa lapponica). Supplement $\mathrm{nr}$ 4. Boden. (Swedish).

\section{Sammanfattning}

Lappugglan har under de senaste årtiondena expanderat åt sydväst i hela Nordvästeuropa (Lawicki et al. 2013). I östra Norge är arten en regelbunden häckfågel sedan slutet av 1980-talet (Solheim 2009a), och 2011 var ett rekordår med 22 häckfynd eller häckningsförsök i Hedmark fylke (Berg et al. 2011). Också i Sverige var 2011 ett mycket bra år, med ett beräknat höstbestånd på 4000-4500 individer (Stefansson 2013). Följande år inkom rekordmånga rapporter till Artdatabanken $\mathrm{i}$ både Sverige och Norge om observerade lappugglor. De flesta rapporterna kom från Sverige.

\section{Metodik}

Hos lappugglor är det tydliga gränser mellan juvenila och adulta ving- och stjärtfjädrar, och ruggningsmönstret kan användas för att ålderbestämma fåglarna, åtminstone efter deras andra vingfjäderruggning (Figur 1, 2 och 3, Solheim 2011). Dessa ruggningsmönster kan också ses på fåglar i fält, och har dokumenterats genom digitalfotografering (Solheim 2009a, 2010, 2011, 2013).

Artdatabanken i Norge och Sverige använder samma databas, utvecklad av det svenska artprojektet som startades 2002. Sökmetodiken är likartad i de två länderna. När rapportörerna dokumenterar sina observationer med digitala foton, kan man hämta ut extra information. Denna studie är ett försök att använda sådan information för att analysera lappugglepopulationens ålderssammansättning under 2012.

Jag laddade ner alla observationer av lappugglor från Sverige och Norge första gången i november 2012 och januari 2013. Denna process upprepades i augusti 2013 eftersom jag efterhand hade fått tillgång till alla observationer i båda länderna. Medan materialet från Norge omfattar 107 enskilda rapporter (varav 49 dolda), var det inte mindre än 4263 enskilda rapporter (varav 265 dolda) från Sverige. I det norska materialet kunde alla dolda rapporter med tillhörande foton hänföras till fyndlokal. I det svenska materialet visade detta sig svårare. I det svenska materialet uteslöts därför de dolda rapporterna. Ålderssammansättningen bland fåglarna i denna lilla del av materialet avviker dock inte från det övriga. Alla rapporter som ledsagades av foton granskades noggrant på en datorskärm med hög upplösning. Alla foton som visade fågelns ålder blev nerladdade för närmare granskning.

Av okänd anledning var antalet rapporterade observationer olika i januari och august 2013. I januari fanns 3103 rapporter som räknades manuellt för att se fördelningen över året (Tabell 2). Rapporterna som laddades ner i augusti 2013 användes slutligen eftersom material från båda länderna var tillgängligt vid denna tidpunkt.

\section{Resultat}

Av de 4105 rapporterna ledsagades 813 (19,8\%) av ett eller flera foton (Tabell 1). Åtminstone ett fotografi kunde i 323 fall användas för att ålderbestämma lappugglan i fråga. Utifrån lokalitetsid-numren gällde dessa rapporter minst 144 individer, varav åtminstone 102 var 2k-fåglar kläckta 2011. Ytterligare nio fåglar klassificerades som troliga 2k-fåglar, medan tio från hösten 2012 var $2 \mathrm{k}+$ med adulta stjärtpennor. Eftersom dessa fåglar teoretisk kan vara antingen från 2011 eller äldre fåglar, blev de uteslutna vid åldersjämförelsen. Om man inkluderar de möjliga $2 \mathrm{k}$-fåglarna från våren med 2011-fåglarna, utgör denna ålderskategori inte mindre än $82,8 \%$ av alla lappugglor som kunde åldersbestämmas 2012 .

Störst antal rapporter kom från landskapen Uppland (1059) och Södermanland (780) (Tabell 1). I Norge kom flest rapporter från kuststräckan mellan "fylkene" Vest-Agder och Østfold. Även i Sverige kom flera rapporter från kustnära områden (Figur 4).

\section{Diskussion}

Den höga andelen unga fåglar är uppenbarligen ett resultat av att 2011 blev det bästa häckningsåret för lappugglor hittills i såväl Sverige (Stefansson 2013) som Norge (Berg et al. 2011). Medan 2011 var ett 
framgångsrikt häckningsår i östra Norge med 22 häckningsförsök, var både 2010 och 2011 goda år I Sverige (77 resp. 81 häckningar eller häckningsförsök; Stefansson 2013). Trots detta kunde bara tre av 134 lappugglor med säkerhet bestämmas till 3k-fåglar. Även om man antar att de 16 fåglarna i kategorin $3 \mathrm{k}+$ var från 2010 , så utgör denna ålderskategori endast $15,7 \%$ av de lappugglor som gick att åldersbestämma. En hypotetisk förklaring på denna låga andel kan tänkas vara att fåglarna kläckta 2010 haft högre mortalitet än fåglarna från 2011. Denna hypotes kan tyckas mindre sannolik då gnagaråret 2010 sträckte sig åtminstone över sommaren och hösten 2011. Ungfåglarna kläckta 2010 borde alltså ha haft mycket goda förhållanden att överleva sitt första levnadsår.

Det är möjligt att ungfåglar har ett annat jaktbeteende än äldre fåglar och oftare samlas på öppna marker nära tätorter när det blir ont om gnagare $\mathrm{i}$ skogstrakterna. Det är dock inte troligt att yngre fåglar löper större risk att trafikdödas än äldre fåglar. Av 69 döda lappugglor från 2012 inlämnade till Riksmuseet, kunde 41 åldersbestämmas enligt tabell i Stefansson (2013). Av dessa var 32 ex. säkra $2 \mathrm{k}$-fåglar, och fyra var troliga $2 \mathrm{k}$-fåglar. Bland de döda lappugglorna utgör alltså ungfåglarna minst $78,0 \%$, och möjligen $87,8 \%$. En annan tolkning kan vara att ungproduktionen av lappugglor 2011 var fem gånger högre än föregående år. Detta kan mycket väl vara förhållandet, åtminstone i den västra delen av lappugglans utbredningsområde i södra Skandinavien, då antal kända häckande lappugglor i östra Norge steg från tre 2010 till 22 under 2011 (Berg 2010, Berg et al. 2011). Enligt Stefansson (2013) studeras lappugglans häckning i Sverige endast på några få platser, och det finns mycket stora områden i landet där kunskap saknas om lappugglans förekomst och reproduktion.

Även om minst 63 lappuggleungar blev flygga i 17 framgångsrika revir i Norge 2011, rapporterades förvånansvärt få lappugglor från Norge 2012. Två lappugglehonor som kontrollerats häckande i Hedmark i Norge 2010 och 2011, kläcktes på två olika boplattformar 440 meter från varandra, väster om Siljan 1999 och 2010. Lappugglornas förmåga att på detta vis förflytta sig $200 \mathrm{~km}$ eller längre kan mycket väl ha fått alla dessa ungfåglar från 2011 att flyga österut och in i Sverige, och således bidragit till den höga andelen av unga fåglar rapporterade därifrån 2012. 